\title{
Determinants of the Commercial Bank's Efficiency in ASEAN
}

\author{
Randi Anto ${ }^{1}$, Irene Rini Demi Pangestuti ${ }^{2}$, Sugeng Wahyudi ${ }^{2} \&$ Eriesta Novia Purwandari ${ }^{2}$ \\ ${ }^{1}$ Doctoral Program in Economics, Universitas Diponegoro, Semarang, Indonesia \\ ${ }^{2}$ Faculty Economics and Business, Universitas Diponegoro, Semarang, Indonesia \\ Correspondence: Irene Rini Demi Pangestuti, Faculty Economics and Business, Universitas Diponegoro, Semarang, \\ Indonesia. Tel: 62-81-2289-5183. E-mail: ird.pangestuti@gmail.com
}

Received: November 11, 2020

Accepted: December 23, 2020

Online Published: January 11, 2021

doi:10.5430/rwe.v12n2p77

URL: https://doi.org/10.5430/rwe.v12n2p77

\begin{abstract}
The purpose of this study is to analyze the influence of capitalization, bank size, bank age, and loan to asset ratio (LAR) to bank efficiency in ASEAN-5 countries (Singapore, Indonesia, Thailand, Malaysia, and the Philippines). Net interest margin (NIM) and non-net interest income (Non-NIM) were used as control variables. There was a total of 58 banks used as a sample using a purposive sampling technique. There were two stages of the analytical method used: data envelopment analysis (DEA) approach - to provide estimates of bank efficiency, and multiple regression linear - consists of the statistical F-test and t-test, coefficient of determination (R2) test and the classic assumption test. The results show that capitalization and bank age affect bank efficiency negatively, while bank size and LAR affect bank efficiency positively. The banks are suggested to consider optimizing their capital to continue to operate efficiently, increase their assets to be more efficient, the older banks are expected to be able to adjust to technological developments, and the banks are also expected to increase the amount of credit by monitoring its quality to be efficient.
\end{abstract}

Keywords: data envelopment analysis (DEA), net interest margin (NIM), loan to asset ratio (LAR), size, age, financial system

\section{Introduction}

\subsection{Background of the Study}

Bank as a financial institution is crucial for the financial system in ASEAN-5 countries. The banking industry has a vital role which makes them have to work effectively and efficiently to sustain in an increasingly globalized economy. In 2015, the ASEAN Economic Community (AEC) came into force in ASEAN (Robiyanto, Hersugondo, \& Chotijah, 2016). The AEC policy in the financial sector (ASEAN Banking Integration Framework (ABIF)) makes the banks more competitive. To increase their competitiveness level, the banks strive to focus on and increase efficiency.

Various input and output indicators can be used to calculate the level of efficiency of the ASEAN-5 banking industry. For example, total capital and total deposits are used as inputs to generate total loans and non-interest income (Chabachib, Windriya, Robiyanto, \& Hersugondo, 2019; Wahyudi, Nofendi, Robiyanto, \& Hersugondo, 2018). Non-performing loans are considered as an undesirable output. Fluctuating movements of inputs and outputs show that there are efficiency problems in the ASEAN-5 banking industry where the efforts to reduce inputs cannot be optimized efficiently and result in increased undesirable output. Although followed by an increase in total loans, a large increase in NPLs as undesirable output shows that the banks had efficiency problems (Adeabah, Gyeke-Dako, \& Andoh, 2019; Atahau \& Cronje, 2015; Puryandani, Kusumawati, \& Robiyanto, 2020).

By focusing on expanding the amount of output produced on owned inputs, bank efficiency can be a measure of a bank's performance. It reflects how successful banks are to transform their resources into desired outputs. Efficiency helps banks to maintain their sustainability and be profitable by making the right business decisions to produce optimum output. Several types of research have examined determinants of bank efficiency, for example, capitalization, bank size, bank age, and loans to assets ratio (LAR). Pasiouras, Tanna, and Zopounidis (2007); Rahim, Md-Nor, Ramlee, and Ubaidillah (2013) investigated determinants of efficiency such as the impacts of capitalization. Previously, Cavallo and Rossi (2010); Pasiouras et al. (2007) found a negative correlation between bank efficiency and capitalization. Meanwhile, Fernandes, Stasinakis, and Bardarova (2018); Mamatzakis, Matousek, and Vu (2016); Partovi and Matousek (2019); Sufian, Kamarudin, and Nassir (2016) found a positive correlation between bank and 
capitalization. Also, Atahau, Cronje, and Majid (2019); Banna, Shah, Noman, Ahmad, and Masud (2019); Cavallo and Rossi (2010); Fernandes et al. (2018) use the economies of scale theory and found that size and efficiency have a positive relationship.

In several studies which used the concept of learning by doing, there was a positive correlation between bank age and efficiency (Partovi \& Matousek, 2019), and in contrast, other studies found that old banks tended to be stiff and obsolete (Adeabah et al., 2019; Fukuyama \& Matousek, 2011). On the other hand, some studies on loan to asset ratio (LAR) by Eyceyurt Batir, Volkman, and Gungor (2017); Garza-García (2012); Sufian et al. (2016) proved that the LAR had a positive effect on efficiency and while other found the opposite (Fernandes et al., 2018; Idris et al., 2011; Maudos, M.Pastor, Pérez, \& Quesada, 2002).

\subsection{The Importance of the Study}

The aforementioned studies regarding the bank's efficiency show different results and being held in one specific country. This implies that there is a research gap on factors that affect efficiency and fluctuations in the input and output of banks that need to be scrutinized. Therefore, it is important to understand the factors that affect bank efficiency. This study will use some variables such as capitalization, bank size, bank age, and loan to asset ratio (LAR), while the control variables were net interest margin (NIM) and non-net interest margin (Non-NIM) as independent variables. This study also using a broader scope which is the ASEAN scope.

\subsection{Literature Review}

Efficiency is defined as the ratio of the sum of weighted output divided by the sum of weighted inputs (Eyceyurt Batir et al., 2017). Its concept can be divided into two groups: technical and allocative efficiency. The company's ability to eliminate waste to produce output in an optimal amount reflected in technical efficiency. Meanwhile, allocative efficiency reflects management's ability to manage a mix of inputs and outputs to minimize costs.

The overall technical efficiency in the banking sector is divided into two types: scale and pure technical efficiency (Pasiouras et al., 2007). Scale efficiency is reflected as the capability of the company at an optimal scale, while pure technical efficiency reflects the capability of the company in minimizing inputs. The measurements can be done with several approaches, such as:

1. Traditional Approach - uses financial ratios such as CAR and ROA owned by the company.

2. Regression Approach - uses a model of an output level as a function of the input.

3. Frontier Approach - maximizes profit or minimizes costs based on the company's best behavior.

Bank's efficiency helps them to gain the community's trust as a good financial institution so that they are willing to save their money (Winarsih \& Robiyanto, 2020). The government has an important role in improving the banks' performance by formulating supportive strategies and policies. In banking efficiency, capitalization is an important factor. It can be defined as the ratio of capital in Tier 1 and 2 to the total assets owned by banks. The greater the ratio, the higher the level of capital to the number of assets owned. A study by Berger and DeYoung (1997) explained that moral hazard was one of the management behaviors. It explains that banks with low capital levels tend to take higher levels of risk because they expect high profitability.

\subsection{Hypotheses Formulation}

High-profit banks are expected to increase production scale which will reduce the average cost per unit so that they can be more efficient. Besides, according to the Regulatory Hypothesis, the regulators enable the banks with low capital to be more efficient and well managed as they find it easy to manage and monitor their credit quality and reduce information asymmetry (Alsyahrin, Atahau, \& Robiyanto, 2018; Dell'Atti, Pacelli, \& Mazzarelli, 2015). This is in line with the concept that bank capital - which is partly derived from third-party funds, aside from being able to generate interest when disbursed - will also lead to a cost of funds if not properly managed. For these reasons, the first hypothesis that can be proposed is that capitalization affects bank efficiency negatively. This is supported by several previous studies such as by Dell'Atti et al. (2015); Eyceyurt Batir et al. (2017); Pasiouras et al. (2007); Rahim et al. (2013). For this reason, hypotheses that can be proposed are as follows:

H1: Capitalization has a negative effect on bank efficiency

Besides, bank size is also one of the crucial factors of bank efficiency. It can be seen from the number of assets, expressed in Ln Total Assets. The assets are important for banks because they must fulfill their financial needs for credit, guarantees, currency trading and insurance securities, financial consulting, and other financial services for customers and investors whose behavior is increasingly globalized (Salvatore, 2005). According to the economies of 
scale theory, the larger the size of the company, the lower the operating costs per unit. The decrease in operating costs per unit happens as the production costs decrease and it is followed by an increase in the number of production units. Therefore, the second hypothesis that can be proposed is that bank size affects bank efficiency positively. This is supported by several previous studies such as by Banna et al. (2019), Fernandes et al. (2018), Sufian et al. (2016), and Cavallo and Rossi (2002). For this reason, hypotheses that can be proposed are as follows:

H2: Bank size has a positive effect on bank efficiency

Also, bank age has been widely studied and found to influence bank efficiency. It reflects how long a company has been operating. The longer the bank operates, the older the bank. According to Leonard-Barton (1992), older banks will be more rigid in carrying out their activities or experiencing obsolescence. They tend to less innovate so that they lose competitiveness, knowledge, and skills. As a result, they become inefficient considering that efficiency can be used to measure the competitiveness level of one bank against another bank. Research by Loderer and Waelchli (2010) explains that older banks would experience a decline in governance, as seen from aging assets, lower margins, and higher costs. The decline in governance would make banks unable to manage their resources optimally, making them less efficient. Thus, the third hypothesis that can be proposed is that bank age affect bank efficiency negatively. This is supported by several previous studies by Adeabah et al. (2019); Fukuyama and Matousek (2011). For this reason, hypotheses that can be proposed are as follows:

H3: Bank age has a negative effect on bank efficiency

Further, the loan to asset ratio (LAR) also influences bank efficiency. The LAR reflects the ratio of the number of loans distributed by banks to the number of assets owned (Eyceyurt Batir et al., 2017). A higher ratio shows that the bank performs the intermediation function properly. Sufian and Akbar Noor Mohamad Noor (2009) explained that a positive relationship between lending activities and bank efficiency is related to the ability of banks to be relatively efficient in managing more productive operations, so that they may be able to have lower costs. The ability of banks to produce at a lower cost has made them able to offer more interesting loan requirements so that its market share becomes even greater. Loans market power refers to the result of efficient operations. The higher the loan, the higher the return rate and it simultaneously increases the scale of operation and bank efficiency. Also, a large number of loans help the banks to be more cost-effective as the cost of managing large and small loans (auditing and notary fees) will be relatively similar. Therefore, the fourth hypothesis that can be proposed is that LAR affects bank efficiency positively. This is supported by several previous studies by Eyceyurt Batir et al. (2017); Garza-García (2012). For this reason, hypotheses that can be proposed are as follows:

H4: Loans to Assets Ratio (LAR) has a positive effect on bank efficiency

\section{Method}

There were two stages of methods used. The first stage was conducting the data envelopment analysis (DEA) method to calculate bank efficiency and then using multiple regression analysis to see the effect of independent variables on the dependent variable. The DEA method was used based on several considerations as follows:

1. It can produce an overall level of efficiency measurements, consisting of pure technical efficiency and scale efficiency.

2. It can accommodate multiple inputs and outputs with a small number of samples.

3. It can produce efficiency measurements that are more accurate than using financial ratios such as Operational Efficiency Ratio (OER).

4. It can compare banking markets of different sizes without imposing certain parametric functional forms within the same constraints.

5. It does not require the research to choose functional forms concerning inputs and outputs.

The DEA method was applied based on the assumption of a variable return to scale (VRS) because the assumption of constant return to scale (CRS) was only suitable when banks operate at an optimal scale. Furthermore, this study used an intermediation approach because the banks used were financial institutions that functioned as institutions distributing funds from surplus parties to parties experiencing deficits. Besides, the bank managers were more flexible to outputs than inputs, where the input was generally limited by various government regulations. This study used output-oriented efficiency.

Furthermore, the intermediation approach chosen also influenced the selection of inputs and outputs used to measure bank efficiency. This study used input which consisted of total loans and total capital, while the output was the 
desired (total loans and non-interest income) and undesirable (non-performing loans) output.

\subsection{Variables}

There was a total of 7 variables used. They consisted of 1 dependent variable, 4 independent variables, and 2 control variables. The dependent variable was bank efficiency measured by the DEA method. The independent variables were capitalization, bank size, bank age, and loan to asset ratio (LAR), while the control variables were net interest margin (NIM) and non-net interest margin (Non-NIM).

\subsection{Population and Samples}

The population of this study was a go-public commercial bank in ASEAN (the big five members, i.e. Indonesia, Thailand, Singapore, Malaysia, and the Philippines) in 2014-2018. The sample was determined using a purposive sampling technique based on the following criteria: 1) listed on the stock exchanges in their respective countries; 2) registered in the Bloomberg terminal, and 3) had complete data in the annual and annual reports for the period of 2014-2018. There was a total of 58 banks used as samples (30 Indonesian banks, 3 Singapore banks, 9 Thai banks, 8 Malaysian banks, and 8 Philippine banks).

\subsection{Data}

The data used in this study was secondary data collected using the document study technique. The data was obtained from annual financial statements published online by each bank during the study period, and the Bloomberg terminal.

\section{$2.4 \mathrm{Model}$}

In the multiple regression analysis, the researchers implemented a descriptive analysis and classic assumption test before doing multiple regression analysis. There were 2 equations used: Model 1 (without control variables) and Model 2 (with control variables). This research used goodness of fit indices to test the control variable. There were 3 hypothesis tests: coefficient of determination, partial significance (t-test), and simultaneous (F-test) test. The regression equations used are as follows:

Model 1 (Without Control Variables)

$$
\text { Efficiency }=\beta \mathrm{o}+\beta 1 \text { Capitalization }+\beta 2 \mathrm{Size}+\beta 3 \mathrm{Age}+\beta 4 \mathrm{LAR}+\varepsilon
$$

\section{Model 2 (With Control Variables)}

$$
\text { Efficiency }=\beta \mathrm{o}+\beta 5 \text { Capitalization }+\beta 6 \mathrm{Size}+\beta 7 \text { Age }+\beta 8 \mathrm{LAR}+\beta 9 \mathrm{NIM}+\beta 10 \mathrm{Non}-\mathrm{NIM}+\varepsilon
$$

Where:

$$
\begin{array}{ll}
\text { Efficiency } & =\text { Bank efficiency } \\
\text { Capitalization } & =\text { Level of bank capitalization } \\
\text { Size } & =\text { Bank size } \\
\text { Age } & =\text { Bank age } \\
\text { NIM } & =\text { Net Interest Margin } \\
\text { Non-NIM } & =\text { Non-Net Interest Margin } \\
\beta 0 & =\text { Constant } \\
\beta 1, \ldots, \beta 10 & =\text { Coefficient of each variable } \\
\varepsilon & =\text { Error }
\end{array}
$$

\section{Results}

Table 1 shows the maximum, minimum, mean, and standard deviation values of each variable (capitalization, bank size, bank age, LAR, NIM, and Non-NM) used in this study.

Table 1. Descriptive statistics of public-listed (commercial) banks in ASEAN

\begin{tabular}{lrrrrr}
\hline \multicolumn{1}{c}{ Variables } & N & \multicolumn{1}{c}{ Minimum } & \multicolumn{1}{c}{ Maximum } & \multicolumn{1}{c}{ Mean } & Std. Deviation \\
\hline Capitalization & 290 & .083 & .479 & .214 & .062 \\
Bank Size (USD Million) & 290 & 142.495 & 149111799.680 & 466319.580 & 1990170.756
\end{tabular}




\begin{tabular}{lrrrrr} 
Bank Age (Month) & 290 & 56 & 1996 & 611.33 & 370.622 \\
LAR & 290 & .001 & .869 & .646 & .114 \\
NIM & 290 & .006 & .142 & .047 & .025 \\
Non NIM & 290 & .001 & .030 & .011 & .006 \\
Efficiency & 290 & .594 & 1.000 & .899 & .089 \\
\hline
\end{tabular}

Source: Bloomberg and Annual Reports, processed.

Table 2. shows that the net interest margin (NIM) and non-net interest margin (Non-NIM) variables have a significance of .025 and $.000(<.05)$. Therefore, both variables can be accepted and used as control variables.

Table 2. Test of control variables on public-listed (commercial) banks in ASEAN-5

\begin{tabular}{|c|c|c|c|c|c|}
\hline & \multicolumn{2}{|c|}{ Unstandardized Coefficients } & \multirow{2}{*}{$\begin{array}{l}\text { Standardized } \\
\text { Coefficients }\end{array}$} & \multirow{3}{*}{$\mathrm{t}$} & \multirow{3}{*}{ Sig. } \\
\hline & & & & & \\
\hline & B & Std. Error & Beta & & \\
\hline Constant & .844 & .014 & & 61.945 & .000 \\
\hline NIM & .459 & .203 & .130 & 2.259 & .025 \\
\hline Non NIM & 2.935 & .818 & .207 & 3.589 & .000 \\
\hline
\end{tabular}

Dependent Variable: Efficiency

Source: Bloomberg and Annual Reports, processed.

Table 3. Result of F-test on public-listed (commercial) banks in ASEAN (Model 1)

\begin{tabular}{|c|c|c|c|c|c|}
\hline Model & Sum of Squares & Df & Mean Square & $\mathrm{F}$ & Sig. \\
\hline Regression & .405 & 4 & .101 & 15.134 & .000 \\
\hline Residual & 1.906 & 285 & .007 & & \\
\hline Total & 2.311 & 289 & & & \\
\hline
\end{tabular}

Source: Bloomberg and Annual Reports, processed.

The result of the F-test is 15.134 with a significance value of $.000(<.05)$. Therefore, the variables in Model 1 (capitalization, bank size, bank age, and LAR) have a significant effect on bank efficiency.

Table 4. Result of F-Test on public-listed (commercial) banks in ASEAN (Model 2)

\begin{tabular}{|c|c|c|c|c|c|}
\hline Model & Sum of Squares & Df & Mean Square & $\mathrm{F}$ & Sig. \\
\hline Regression & 180.255 & 6 & 30.042 & 8.239 & .000 \\
\hline Residual & 1031.901 & 283 & 3.646 & & \\
\hline Total & 1212.156 & 289 & & & \\
\hline
\end{tabular}

Source: Bloomberg and Annual Reports, processed.

The result of the F-test is 8.329 with a significance value of $.000(<.05)$. Therefore, the variables in Model 2 (capitalization, bank size, bank age, LAR, NIM, and Non-NIM) have a significant effect on bank efficiency. 
Table 5. Result of t-test and coefficient determination on public-listed (commercial) banks in ASEAN (Model 1 and Model 2)

\begin{tabular}{|c|c|c|c|c|c|c|c|c|}
\hline & \multicolumn{3}{|c|}{ Without Control Variables } & \multicolumn{5}{|c|}{ With Control Variables } \\
\hline & \multicolumn{2}{|c|}{$\begin{array}{l}\text { Unstandardized } \\
\text { Coefficients }\end{array}$} & \multirow{2}{*}{$\begin{array}{c}\text { Standardized } \\
\text { Coefficients } \\
\text { Beta }\end{array}$} & \multirow[t]{2}{*}{ Sig. } & \multicolumn{2}{|c|}{$\begin{array}{c}\text { Unstandardized } \\
\text { Coefficients }\end{array}$} & \multirow{2}{*}{$\begin{array}{c}\begin{array}{c}\text { Standardized } \\
\text { Coefficients }\end{array} \\
\text { Beta }\end{array}$} & \multirow[t]{2}{*}{ Sig. } \\
\hline & B & Std. Error & & & B & Std. Error & & \\
\hline (Constant) & .793 & .043 & & .000 & .764 & .041 & & .000 \\
\hline Capitalization & -.342 & .078 & -.238 & .000 & -.480 & .075 & -.334 & .000 \\
\hline SIZE & .005 & .002 & .133 & .017 & .004 & .002 & 109 & .051 \\
\hline AGE & -4.098 & .000 & -.170 & .002 & -5.079 & .000 & -.211 & .000 \\
\hline LAR & .237 & .043 & .303 & .000 & 231 & .040 & 296 & .000 \\
\hline NIM & & & & & .672 & .195 & 190 & .001 \\
\hline Non-NIM & & & & & 3.995 & .772 & .281 & .000 \\
\hline Adjusted $\mathrm{R}^{2}$ & .171 & & & & & & & \\
\hline
\end{tabular}

Source: Bloomberg and Annual Reports, processed.

Based on Table 5., the multiple linear regression of model 1 (without control variables) can be arranged as follows:

$$
\text { Efficiency }=.793-.342 \text { Capitalization }+.005 \text { Size }-4.098 \text { Age }+.237 \mathrm{LAR}+\varepsilon
$$

While the multiple linear regression of model 2 (with control variables) can be arranged as follows:

$$
\text { Efficiency }=.764-.480 \text { Capitalization }+0.004 \text { Size }-5.079 \text { Age }+.231 \mathrm{LAR}+.672 \mathrm{NIM}+3.995 \text { Non-NIM }+\varepsilon \text { (4) }
$$

Also, Table 5 shows that the coefficient of determination (Adjusted $\mathrm{R}^{2}$ ) of Model 1 is .171 or $17.1 \%$. It means that $17.1 \%$ of the efficiency variables can be explained by capitalization, bank size, bank age, and LAR, while the remaining $82.9 \%$ can be explained by other factors not included in the research model. Then, the coefficient of determination (Adjusted $\mathrm{R}^{2}$ ) of Model 2 is .263 or $26.3 \%$. This means that the NIM and Non-NIM as control variables could improve the ability of the model in explaining efficiency. As much as $26.3 \%$ of the efficiency variables can be explained by capitalization, bank size, bank age, LAR, NIM, and Non-NIM, while the rest 73.7\% can be explained by other factors not included in the research model.

\begin{tabular}{|c|c|c|c|}
\hline No. & Description & $\begin{array}{c}\text { Without Control } \\
\text { Variables }\end{array}$ & With Control Variables \\
\hline 1 & Adjusted R-Square & $17.1 \%$ & $26.3 \%$ \\
\hline 2 & Capitalization & $\begin{array}{l}\text { Has a negative } \\
\text { significant effect }\end{array}$ & $\begin{array}{l}\text { Has a negative } \\
\text { significant effect }\end{array}$ \\
\hline 3 & Bank Size & $\begin{array}{l}\text { Has a positive } \\
\text { significant effect }\end{array}$ & $\begin{array}{l}\text { Has a positive } \\
\text { significant effect }\end{array}$ \\
\hline 4 & Bank Age & $\begin{array}{l}\text { Has a negative } \\
\text { significant effect }\end{array}$ & $\begin{array}{l}\text { Has a negative } \\
\text { significant effect }\end{array}$ \\
\hline 5 & Loan to Asset Ratio (LAR) & $\begin{array}{l}\text { Has a positive } \\
\text { significant effect }\end{array}$ & $\begin{array}{l}\text { Has a positive } \\
\text { significant effect }\end{array}$ \\
\hline
\end{tabular}

Table 6. Summary of the effects of control variables

Source: Bloomberg and Annual Reports, processed.

\section{Discussion}

The results of the t-test show that capitalization has a negative and significant effect on bank efficiency. The greater the level of bank capitalization, the lower the bank efficiency. It happened because public-listed (commercial) banks 
already had a high level of capitalization. Therefore, greater capitalization would cause difficulties in management and make banks inefficient. The banks with low capital would take a higher level of risk, expecting higher profitability. A higher rate of return would increase the scale of operation, making the banks to be more efficient. The results of this study are in line with Dell'Atti et al. (2015); Pasiouras et al. (2007); Rahim (2017); Rahim et al. (2013).

Besides, the t-test also proves that bank size has a positive and significant effect on bank efficiency. The greater the bank size (reflected by several assets owned), the more efficient the bank. It happened as banks with large assets would tend to enjoy the cost advantage of economies of scale. It was also consistent with the economies of scale theory that when a company has a larger size, the operating costs per unit will be lower. The results of this research are in line with previous studies conducted by Banna et al. (2019); Cavallo and Rossi (2010); Fernandes et al. (2018); Sufian et al. (2016).

This study also proves that bank age has a negative and significant effect on bank efficiency. The older the bank, the less efficient the bank would be. It was because older banks generally had a rigid tendency that caused the loss of competitiveness, skills, and obsolescence as they did not innovate. The loss of competitiveness caused them to become less efficient, where efficiency could be used to measure competitiveness. Also, the older banks generally experienced a decline in governance reflected by older assets and slow margin growth so as not to be able to optimize their resources which caused banks to become inefficient. The results of this study are following previous studies conducted by Adeabah et al. (2019).

Furthermore, the results of the t-test show that LAR has a significant positive effect on bank efficiency. The higher the loans, the more efficient the bank would be. This was because the loans were the main product of banks. A higher level of loans distributed resulted in a greater return rate and it implied that the loans did not have a high risk. Increasing the return rate on these assets would increase the scale of production and make the banks more efficient. Also, larger loans helped the banks to be more cost-effective as the management costs of large and small loans would be similar (audit fees and notary leases). Therefore, the banks would be more efficient if the loan was getting bigger. The results of this study are consistent with Eyceyurt Batir et al. (2017); Garza-García (2012).

The results of the t-test show that capitalization affects the efficiency of go-public (commercial) banks in ASEAN negatively. The banks with large capital would generally experience difficulties in managing it, resulting in a large cost of funds and impacts on decreasing efficiency. This study also proves that bank size affects bank efficiency positively. The greater the number of assets owned by the bank, the more efficient the bank would be. This happened due to the cost benefits from economies of scale. However, it was found that bank age affects bank efficiency negatively. The older the bank, the less efficient the bank would be. It was because the older banks tend to be rigid, experienced obsolescence over technology compared to younger banks, and experienced a decline in governance. Further, the results of the t-test also show that the loan to asset ratio (LAR) has a positive and significant effect on efficiency. The higher the number of loans, the more efficient the bank would be as the banks would get a higher rate of return on assets. This simultaneously would increase the scale of production and help the banks to become more efficient.

Based on the results of this research, there are several suggestions for banks. First, the banks are suggested to consider optimizing their capital to continue to operate efficiently. Second, the banks are also suggested to increase their assets to be more efficient as they enjoy the benefits of economies of scale. Third, the older banks are expected to be able to adjust to technological developments so they can manage resources more optimally and be more efficient. Finally, the banks are also expected to increase the amount of credit by monitoring its quality to be efficient.

There are also several limitations to this study. First, the Adjusted R-Square value of this study is still relatively low at only $26.3 \%$. This means that there are still $73.7 \%$ of other variables outside the study that can explain bank efficiency. Therefore, future researches are expected to add other variables that have not been included in this research. Second, this research is still global where it only tried to measure bank efficiency and understand factors influencing it in go-public (commercial) banks in ASEAN. Thus, it is still unobvious whether there are differences in characters among banks in Indonesia and non-Indonesian banks included in the ASEAN.

\section{References}

Adeabah, D., Gyeke-Dako, A., \& Andoh, C. (2019). Board gender diversity, corporate governance and bank efficiency in Ghana: a two stage data envelope analysis (DEA) approach. Corporate Governance: The International Journal of Business in Society, 19(2), 299-320. https://doi.org/10.1108/CG-08-2017-0171 
Alsyahrin, D. P., Atahau, A. D. R., \& Robiyanto, R. (2018). The effect of liquidity risk, financing risk, and operational risk toward Indonesian Sharia Bank's financing with bank size as a moderating variable. Journal of Economics, Business \& Accountancy Ventura, 21(2), 241-249. https://doi.org/10.14414/jebav.v21i2.1181

Atahau, A. D. R., \& Cronje, T. (2015). Loan Portfolio Structure and Performance of Government Owned Banks in Indonesia: Does Size Matter?. Corporate Ownership \& Control, 11(4).

Atahau, A. D. R., Cronje, T., \& Majid, M. S. A. (2019). Mode of entry, loan portfolio structure, and returns of foreign-owned banks in Indonesia. Journal of International Studies, 12(2), 99-116. https://doi.org/10.14254/2071-8330.2019/12-2/6

Banna, H., Shah, S., Noman, A., Ahmad, R., \& Masud, M. (2019). Determinants of Sino-ASEAN Banking Efficiency: How Do Countries Differ?. Economies, 7(1). https://doi.org/10.3390/economies7010013

Berger, A. N., \& DeYoung, R. (1997). Problem loans and cost efficiency in commercial banks. Journal of Banking \& Finance, 21(6). https://doi.org/10.1016/S0378-4266(97)00003-4

Cavallo, L., \& Rossi, S. P. S. (2010). Do environmental variables affect the performance and technical efficiency of the European banking systems? A parametric analysis using the stochastic frontier approach. The European Journal of Finance, 8(1), 123-146. https://doi.org/10.1080/13518470110076277

Chabachib, M., Windriya, A., Robiyanto, R., \& Hersugondo, H. (2019). A comparative study of Indonesian and Malaysian Islamic banks. Banks and Bank Systems, 14(4), 55-68. https://doi.org/10.21511/bbs.14(4).2019.06

Dell'Atti, S., Pacelli, V., \& Mazzarelli, G. (2015). The efficiency of the European banking groups and its determinants. Managerial Finance, 41(7), 734-751. https://doi.org/10.1108/MF-12-2013-0335

Eyceyurt Batir, T., Volkman, D. A., \& Gungor, B. (2017). Determinants of bank efficiency in Turkey: Participation banks versus conventional banks. Borsa Istanbul Review, 17(2), 86-96. https://doi.org/10.1016/j.bir.2017.02.003

Fernandes, F. D. S., Stasinakis, C., \& Bardarova, V. (2018). Two-stage DEA-Truncated Regression: Application in banking efficiency and financial development. Expert Systems with Applications, 96, 284-301. https://doi.org/10.1016/j.eswa.2017.12.010

Fukuyama, H., \& Matousek, R. (2011). Efficiency of Turkish banking: Two-stage network system. Variable returns to scale model. Journal of International Financial Markets, Institutions and Money, 21(1), 75-91. https://doi.org/10.1016/j.intfin.2010.08.004

Garza-García, J. G. (2012). Determinants of bank efficiency in Mexico: a two-stage analysis. Applied Economics Letters, 19(17), 1679-1682. https://doi.org/10.1080/13504851.2012.665589

Idris, A. R., Asari, F. F. A. H., Taufik, N. A. A., Salim, N. J., Mustaffa, R., \& Juso, K. (2011). Determinant of Islamic Banking Institutions' Profitability in Malaysia. World Applied Sciences Journal, 12(Special Issue), 1-7.

Leonard-Barton, D. (1992). Core capabilities and core rigidities: A paradox in managing new product development. Strategic Management Journal, 13(S1), 111-125. https://doi.org/10.1002/smj.4250131009

Loderer, C., \& Waelchli, U. (2010). Firm age and performance. MPRA Paper. Retrieved from https://mpra.ub.uni-muenchen.de/26450/1/age_performance.pdf

Mamatzakis, E., Matousek, R., \& Vu, A. N. (2016). What is the impact of bankrupt and restructured loans on Japanese bank efficiency?. Journal of Banking \& Finance, 72, S187-S202. https://doi.org/10.1016/j.jbankfin.2015.04.010

Maudos, J. N., M.Pastor, J., Pérez, F., \& Quesada, J. (2002). Cost and profit efficiency in European banks. Journal of International Financial Markets, Institutions and Money, 12(1), 33-58. https://doi.org/10.1016/S1042-4431(01)00051-8

Partovi, E., \& Matousek, R. (2019). Bank efficiency and non-performing loans: Evidence from Turkey. Research in International Business and Finance, 48, 287-309. https://doi.org/10.1016/j.ribaf.2018.12.011

Pasiouras, F., Tanna, S. K., \& Zopounidis, C. (2007). Regulations, Supervision and Banks' Cost and Profit Efficiency Around the World: A Stochastic Frontier Approach. University of Bath Management Working Paper. Retrieved from https://papers.ssrn.com/sol3/papers.cfm?abstract_id=970373

Puryandani, S., Kusumawati, H. A., \& Robiyanto, R. (2020). Corporate Governance and Earnings Management Practices in Indonesian Banking Sector. Quality - Access to Success, 21(176), 102-108. 
Rahim, R. A. (2017). Efficiency and Competition in the Malaysian Banking Market: Foreign versus Domestic Banks. Gadjah Mada International Journal of Business, 19(2), 193-221. https://doi.org/10.22146/gamaijb.6106

Rahim, R. A., Md-Nor, N. G., Ramlee, S., \& Ubaidillah, N. Z. (2013). Determinants of cost efficiency in Malaysian banking. International Journal of Business and Society, 13(3), 355-374.

Robiyanto, R., Hersugondo, H., \& Chotijah, G. S. (2016). ASEAN Economic Community (AEC) and Economic Stability: A Review from Indonesia's Side. International Journal of Economic Research, 13(2).

Salvatore, D. (2005). Ekonomi Manajerial dalam Perekonomian Global (5th ed., Vol. 1). Jakarta, Indonesia: Salemba Empat.

Sufian, F., \& Akbar Noor Mohamad Noor, M. (2009). The determinants of Islamic banks' efficiency changes. International Journal of Islamic and Middle Eastern Finance and Management, 2(2), 120-138. https://doi.org/10.1108/17538390910965149

Sufian, F., Kamarudin, F., \& Nassir, A. m. (2016). Determinants of efficiency in the malaysian banking sector: Does bank origins matter?. Intellectual Economics, 10(1), 38-54. https://doi.org/10.1016/j.intele.2016.04.002

Wahyudi, S., Nofendi, D., Robiyanto, R., \& Hersugondo, H. (2018). Factors affecting return on deposit (ROD) of sharia banks in Indonesia. Business: Theory and Practice, 19, 166-176. https://doi.org/10.3846/btp.2018.17

Winarsih, W., \& Robiyanto, R. (2020). The Sharia supervisory board and corporate social responsibility disclosure: A Sharia perspective in Indonesia. Humanities \& Social Sciences Reviews, 8(1), 821-828. https://doi.org/10.18510/hssr.2020.8198

\section{Copyrights}

Copyright for this article is retained by the author(s), with first publication rights granted to the journal.

This is an open-access article distributed under the terms and conditions of the Creative Commons Attribution license (http://creativecommons.org/licenses/by/4.0/). 